American Research Journal of English and Literature

ISSN (Online)-2378-9026

Volume 4, Issue 1, 2018, 1-12 Pages

DOI:10.21694/2378-9026.18001

\title{
Impediments for Research Writing in Bangladesh: Steps and Potentiality
}

\author{
Md. Amir Hossain \\ Senior Faculty, Department of English \\ IBAIS University, Bangladesh \\ amir.hossain.16578@gmail.com
}

\begin{abstract}
Without research writing the potentiality as well as development of Bangladesh Educational Institutions cannot be expected, especially for the Undergraduate and Graduate Level. There is no alternative way of research writing whether educational institutions want to cope with the Global Education System. To develop the essence of Education System, younger communities must be motivated in research writing. In a third world country, like Bangladesh, there are many impediments, which are significantly noticed in research writing. In this study, the current researcher would like to find out some major impediments for research writing in Bangladesh situation. Through highlighting these barriers, this study would like to create consciousness of the younger generation for the better welfare of the Current Education System. It also aims to look at the investigations of pragmatic solutions through which the prevalent obstructions of scholarly writing can be identified in a surer foundation in order that each and every teacher and researcher of the higher level can find out a free gate of research writing.

\section{INTRODUCTION}

Research Writing is the key to success and development of Education System of any country around the globe. Without research writing no education system of a nation or a country cannot be improved. In this regard, I can mention a famous maxim of Napoléon Bonaparte: "If you give me a good educated mother, I will give you a good educated nation." It is quite true that no nation can progress without education. Of course education system must be connected with research writing in $21^{\text {st }}$ - century competitive age. The whole global education system is undergoing a significant change based upon research writing; it is a matter of great regret that our Bangladesh Education System is lagging behind in comparison with the European Education System. In Bangladesh, there are a lot of hindrances and barriers of education system concerning research writing. Our scholars and teachers are not conversant with research project, especially in philological studies. The project that they plan to conduct is very back dated. They fail to carry out a scholarly project in the light of very recent time. Their project is far away from the European scientific project. Scientific project should be dealt with postmodern times according to the demand of the age literature.

The younger teachers and novice researchers should be motivated and inspired in order that they can be able to carry out a scientific scholarly research writing authentically and practically. They would be assertive, positive, supportive, research oriented and meditative to research writing so that they can bring about a significant change of Bangladesh Education System. If the education policy of a country cannot be developed and polished, we cannot expect a better tomorrow in the field of research methodology. So the Government as well as the conscious citizen of the country should come forward to develop the current situation.

To get rid of impediments and obstructions of research writing, I would like to motivate young research scholars and teachers of Bangladesh so that they should be conscious and sensitive of scholarly research writing. Through

www.arjonline.org

Page 1 
this project, my plan is to find out practical solution so that our scholars and teachers can be able to cope with the $21^{\text {st }}$ - century age of the globe around.

For this task, the Government should establish Research Centre at each and every institution of tertiary level across the country. The Government should increase research budget for the poor and meritorious students so that they can carry out a scholarly research project in any branches of epistemology.

Research writing should be our only motto. To fulfil this expectation, scholars and teachers should be research oriented: One aim, one target, and one task. To do so, younger generation need to practise scholarly research writing for the betterment of Bangladesh Education System. Then it is possible for all of us to remove all sorts of impediments on the way to research writing. It is the duty as well as responsibility of all teachers, research scholars, and writers of any branches of knowledge should keep themselves busy to upgrade the current Bangladesh situation.

\section{Aims \& OBJECTIVES OF THE STUDY}

To fulfil the aims and objectives of this study, I would like to focus upon my logics and arguments so that young researcher can be able to solve obstructions of research writing in Bangladesh situation. Research writing would bring about a significant change of Bangladesh Education System; as a result, research scholars would be able to reach the expected goals in real life situation. Without aims and targets, no man can come out successful; and life would be beautiful and meaning if there is an honest aim in life. In this respect, I would like to mention some points of aims and objectives as follows:

* To take concerted efforts so that researchers can be successful in conducting a scholarly project;

* To increase research budget so that younger communities can apply their practical knowledge in a potential research project;

* To Provide funding supports for the poor and meritorious researchers by the Government, Private Organization, the Stipend of the University;

* To cope with the European countries, expert supervisors should be appointed at the University;

* Try to establish Research Centre across the country so that every student can learn research methodology;

* To investigate scientific project for the welfare of Educational Institutions;

* To identify the barriers of research writing and try to solve them immediately;

* Try to create consciousness regarding plagiarism;

* To motivate the younger teachers and researchers in ultra-modern oriented research writing;

* To inspire the rich so that they can help the poorer students carry out a scientific research project;

* Take pragmatic steps so that science and technology oriented research project can be ensured.

\section{RESEARCH QUESTIONS}

Based on the background of the study, and knowledge of research methodology, the present researcher has formulated and posed the central research question to be explored and addressed in this scientific project. Here, the central research question is as follows: What types of impediments are presented as 10 key points in conducting this research writing? While addressing this central research question, some minor questions have also been raised, which are the following: 
Impediments for Research Writing in Bangladesh: Steps and Potentiality

1. In what ways do younger teachers and researchers face financial crisis for conducting a scientific research project?

2. What steps seem to have taken to upgrade Bangladesh situation?

3. To what extends can Bangladesh Education System be developed?

4. How does the current scientific research project bring about a significant change for the betterment of Bangladesh Educational Institutions?

\section{IMPEDIMENTS FOR RESEARCH WRITING IN BANGLADESH}

In the light of Bangladesh situation, there are several noticeable impediments for research writing, for which young teachers and research scholars cannot carry out their scientific project in time. We have limited resources and funding opportunity for the researchers for which they have to face much hurdles and complexities at every step of research writing in Bangladesh situation. In the third worlds country, the big challenge for the researchers is funding problem. If there is no funding opportunity for the researchers, how they can be able to conduct their project. To unveil some major impediments in current Bangladesh situation, I have mentionedthem so that each and every teacher and researcher is very conscious of conducting scientific research project. They are as follows:

\section{Economic Crisis}

Economic Crisis is one the major causes for research writing in Bangladesh situation. Most of the people of our country are very poor and economically handicapped and they cannot afford to meet the minimum basic materials of scholarly writing. Due to economic crisis, many brilliant students cannot be able to purchase necessary materials of scientific project for any type of scholarly writing. Those who live in the villages have no single sense of research methodology and scholarly writing. They cannot get experts and supervisors from whom they can be able to learn research knowledge. In our country, there are many meritorious students, teachers and research scholars, but the major problem is that nobody has any intention and mentality to help each other. On the contrary, those who are very eager to learn from the research knowing persons have no opportunity to go to them, and as a result, are fully deprived of scholarly writing, the major problem is that the research knowing persons are very busy to earn money for their own interest, they have no time to spend for them. So this miserable plight of scientific research project can describe in word or language.

Bangladesh, as a third world country, cannot meet the demand of research writing for the new scholars due to economic impediments. They have no financial ability to participate in the international conference, workshop, and seminar, symposium, and round table talks around the world. If it is not feasible for them to get mixed with the different communities and cultures, now a question arises in our mind that how they can be able to carry out their scientific research project in their respective filed. In this way our younger generation are lagging behind from the practice of research writing day by day in Bangladesh.

Another issue can be added in this regard: Our Government cannot afford to meet the necessary materials of research project for the younger scholars and teachers due to poor research budget. Anyway, methinks that economic crisis is one of the big challenges for scholarly writing.

\section{Lack of Suitable Sources}

If the government cannot meet the demand of suitable sources for research writing, research scholars cannot develop their scientific project. To carry out the research project, funding sources are very much essential. The reason is that he has to purchase books, journals, articles, primary and secondary sources to carry out the project, but he fails to do so, he cannot proceed further. As we know ours is a very developing country in the 
world, we have lots of lack of financial supports. Our government cannot afford to provide financial supports for the research scholars. As a result, many scholars fall apart from main pursuit. This current situation is very much prevalent in Bangladesh.

Another important issue may be mentioned in this regard:our scholars have no financial ability to go to abroad for research purpose. They have no ability to buy books from abroad; they have no ability to participate or present paper in the international conferences; they cannot participate in symposium, round talks, and workshop in the world around. They are deprived of scientific methods and tools. At this critical situation how they can be able to innovate and find out a perfect aspect of their project. On the contrary, if we look at the European research scholars, we would see that they get a lot of funding supports from the government or the stipend from the institutions. They can travel any time for their research project everywhere in the world. Whenever they wish to participate or to present paper in the international conferences, research grants are provided for them. They don't have to face any financial crisis for their research project. But in Bangladesh we have to tackle many impediments for research writing.

We have only limited funding supports or scholarships for the research scholars. Consequently, they cannot carry out their project. To provide suitable sources for the research scholars, our government as well as the concerned authority of the Universities come forward to upgrade this situation.

\section{Poor Research Funds}

Bangladesh is a very low income country in the planet. She cannot afford to meet research supports for the young teachers and scholars. She has to face political and economic crisis at every step of research funding. Our scholars and teachers cannot conduct their project in time due to poor financial aids. Moreover, in Bangladeshi Universities and Colleges, there are very limited stipends for which our scholars cannot go ahead, even despite merit and intelligence, they cannot dream to carry out the research project at home let alone in abroad.

Our government is not conscious of funding opportunities for the meritorious students. We all know that without funding supports, we cannot be able to conduct a suitable research project. If this situation happens, we cannot expect a better tomorrow in the light of research methodology. Again if we look at international research funding opportunity beyond our country, we would see that the researchers can enjoy a lot of funding opportunities from the government and from the institutions. But in our country the situation is totally opposite. For the research development the research scholars can travel around the world whenever they feel the necessity, but whereas our researchers cannot travel to the neighbouring country due financial crisis.

Though our government cannot afford to meet the demands of research tools and methods for the young research scholars, we should sit in idleness; rather we should try heart and soul to upgrade the situation at any cost. We have no time to look behind; we must go ahead. By hook or by crook we must alter a revolutionary change of research writing among the research scholars across the country. In this regard, our motto ought to be one aim, one dream, and one expectation then we would be able to come out successful.

We know that we have poor research funds, yet we should not blame our lot or situation, we should work together without any debates and without any conflicts. The government as well as the conscious citizens of the country should come forward to increasing the research funds among the poor and economically weaker research scholars of the country right now.

\section{Shortage of Science and Technology}

Without the development of science and technology, any country of the globe cannot tackle the situation properly. If we look at the scientifically and technologically developed countries of the world, we can see that their research project is perfect and authentic due to science and technology. It is known to all of us that the more science and technology is developed, the more research project is developed. It is a matter of bad luck 
for us that Bangladesh is not scientifically and technologically prosperous and potential in comparison with the developed countries of the world. That's why we cannot carry out our research project perfectly and authentically. We have lots of lack of the utilization of science and technology in our country. To increase the proper use of science and technology, the government and the conscious people of the country will have to take pragmatic and fruitful steps without making any delay.

If we would like to conduct our research project in a proper way, we must ensure the right use of science and technology with a view to creating consciousness among our research minded persons in the country. It is very interesting to mention that research funding is very much provided among the research scholars in the field of science and technology around the globe. So the research scholars must be inspired towards scientific and technological research project, since the prosperity and failure of the country largely depends upon science and technology. In this regard, the younger generation of the country must be utilized and motivated so that they can be able to contribute to research work. They must be given proper guidance so that they can be able to realize the inner significance of research writing. To remove the shortage of science and technology, all sorts of people of the country will have to be devoted to research project.

\section{Lack of Research Centre}

Research scholars cannot imagine the existence of research project without research centre in any country of the globe. Research centre can play a dominant role for the potentiality and innovation of scholarly writing. Research centre is a must for the younger generation of Bangladesh. If we look at the research centres of European countries, we would realize that their research centres are highly developed and powerful. Younger research scholars can get all sorts of facilities for their research project. Scholarship and funding supports are provides for them in such research centre in order that they can be able to conduct their project without any financial crisis. To develop the research project, the government and the concerned authority of the University are always careful of the research scholars. As a result, the scholars don't face any hurdles and complexities in carrying out their scientific research project.

But, in Bangladesh there are very limited numbers of research centres. Though research centres are established in the universities, most of the students are not very much interested in conducting their research writing in the research centres. Another major problem may be mention that such centres cannot afford to provide necessary materials and funding supports for the research scholars. Moreover our budget for research project is very poor, for which our scholars lose their mental satisfaction in carrying out their scholarly project. Since Bangladesh is a very developing country in the globe, our government cannot afford to meet the minimum necessities of the scientific research project.

Therefore, the government as well as the conscious people of the country should come forward with a view to bringing about a revolutionary change in the field of research methodology across the country. In this regard, our research scholars ought to be motivated and inspired so that they can never dishearten to carry out their scientific research project.

\section{Lack of International Conference, Seminar, Symposium, and Workshop}

In my opinion, the main source of research writing is originated from international conference, seminar, symposium, and workshop for any type of researcher. Different types of research experts, intellectuals, and specialists gather together from many countries of the world and they discuss many issues from various icons. Since they have visited many countries of the planet and have possessed a vast knowledge upon many subjects. If they motivate the young researchers for scholarly project, the young scholars can learn new tools and method of scientific research project from them. It is possible for them to get entangled with the renowned personnel of the world through organizing international conference.

American Research Journal of English and Literature

Page 5 
In the developed countries of the world, many educational institutions organize the international conferences and workshops almost all the year round. As a result, students are properly benefitted and they can be able to gather research skill very easily. On the contrary, the many developing countries, including Bangladesh, international conference, seminar, symposium, and workshop are organized after a long time. Even many public universities are not interested to organize such programs; they think if such programs are organized, they have to spend a lot of finance, and also they argue the point that they have funding problem at the university. If this crisis happens, how young research scholars and teachers can be able to acquire research knowledge. As a result, they are lagging behind in comparison with the high ranking universities of the globe. They are fully deprived of scientific research project. It is seen through the survey of research that the research titles of M. Phil and PhD program in the developing countries are very much back dated in comparison with the European Universities. Our research is dealt with the thematic discussion, but the European research is on theoretical based, which is very innovative and potential. Anyway, to overcome such impediments and complexities of potential research project, we must organize the international conferences and workshops so that our research scholars and young teachers can be motivated into research writing.

\section{Want of Proper Knowledge for Research Writing}

If there is no proper knowledge of research writing, no research scholar can come out successful in carrying out a scientific research project. To conduct a scientific project properly, research skill is a must. Novice researcher cannot complete research writing very successfully because he has a poor commanding of research knowledge. In this regard, I mean by research knowledge that he must have a proper sense of tools, methods, style, citation, research, data collection, data analysis, literature review, theoretical knowledge, acknowledgement, and above all, critical and creative writing skill. In a word, without research knowledge, a research scholar cannot be successful in carrying out his research project.

To learn proper research skill, he needs to take research training from research centre. Those who get involved into research writing can provide research knowledge among the young researcher or novice researcher. At this situation, a young scholar has to rely upon a literary and linguist expert, who professionally trains his researcher.

However, in Bangladesh situation, there are very small number of research knowing persons who have vast ideas and thoughts regarding research knowledge. The main reason is that they are not internationally trained-up in comparison with European scholars. Their research writing is mostly updated, but our project is backdated. We have no critical sense of applying theory; we just try to complete the whole project through thematic formulae. As we know that research is of two types: theoretical research and thematic research. But we in most cases follow thematic research. We are very far away from theoretical research and scientific research.

Another problem needs no telling the fact that in Bangladesh, supervisors are not attentive to their students and they have a notion that it is a lengthy process; they have no time to review and correct the whole project for evaluation. Before submitting for reviewers' decision, it is the first and foremost duty and responsibility of the supervisors is to edit and revise the whole project done by the researcher. In the light of Bangladesh, I sense that both of the supervisor and researcher ought to gather proper research knowledge. If they fail to do so, a country cannot be able to reach an optimistic aim in the field of research knowledge.

\section{Poor Management System of Bangladesh Education System}

Research writing of a country largely depends upon her education system. If her education system is not related to research practice, she cannot produce a good offspring. She must have a proper system of research practice among teacher, research scholar, and practitioner. To change the situation of research knowledge, education system must be updated scientifically and technologically. The younger generation of the country must be motivated into scientific and technological education system in order that they can be able to utilise education 
system for their real life situation. To do so, they must come to realise the essence of research writing. Otherwise, day to day, they begin to lag behind. To bring about a significant change of education system of a country, the younger generation should come first. The experts should motivate them how to develop scientific research project so that such project is suitable for the contemporary times.

In a developing country, like Bangladesh, education system is not much developed and practical oriented in comparison with the scientifically and technologically developed countries of the planet. Education system must be connected to research oriented to meet the demand of any age so that research scholar can get a better living through his practical research knowledge.

To change the education system of Bangladesh, the governmentand the University scholars should take pragmatic steps, for example, international conference, workshop, symposium and mini talks should be organized; in this regard, the participation of international research scholars must be ensured. The research practice of science, arts, and commerce must be equally emphasized. At first education system of the country must be brought about a revolutionary change in such way that it must be career oriented for all sorts of people. But the poor management system exists for a long time, nobody can expect for a better outcome of research writing. Today or tomorrow we must change the current education system. Here lies the inner success of research writing.

\section{Propensity of Income Source}

In Bangladesh research practice cannot much progress due to the propensity of income source in this sense when a teacher gets enabled to acquire research knowledge in a respective field, he always tries to seek his earning source; he feels pride of research skill in such way that nobody is equal to him. A famous proverb may be mentioned in this regard: "Pride down himself." A research knowing person should not have a notion like this one. If it prevails in his mind, he cannot become a successful research scholar, rather he should be liberal minded so that he can spread his earned knowledge among his disciples, for example we can say that a tree is known by its fruit. Trunk of a banyan tree cannot be used for fashionable furniture, but its shade is very comfortable; many people come to take rest under the banyan tree.

Similarly, a conceited researcher cannot be a popular figure among his circles, for this he has to sacrifice himself for the greater welfare of the novice researchers. Knowledge is never limited, rather it has a vast area, and it always increases unlimitedly like grass. Knowledge spreads through practice. Research knowledge cannot be finished. Research writing cannot be like a product, it cannot be earned by money, and we must labour hard and sweat for it. Then we can be a pure lover of research knowledge.

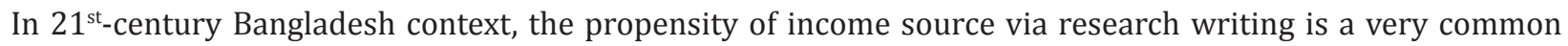
affair among teachers, researchers, and practitioners. We should give up an outworn idea, like a little learning is a dangerous thing. A real research knowing scholar cannot be selfish; besides earning money he will have to have practical mind so that he can earn popularity and familiarity of research knowledge. If this happens in him, he must become a age oriented scholar across the country. It should be our real motto.

\section{Minority Complex}

Minority complex is a problem of research writing. Many researchers in Bangladesh have a tendency of depreciating novice researchers. The research knowledgeable person should not demean and derogate other researchers while they train and supervise them. If minority complex exists in teachers' and supervisors' mind, novice researchers cannot expect a good research project from them and even they cannot come out successful in carrying out a scientific research project. If anybody belittles others in educational institution, he cannot be a "top ten." To hold his position, he must try to satisfy all and sundry.

A research knowing person by hook or by crook always tries to avoid minority complex. If any researcher has no basic knowledge on research writing, it is the duty and responsibility of a knowledgeable person teaches novice researchers so that they can be able to apply their own experiences in conducting a scientific project.

American Research Journal of English and Literature

Page 7 
Anyway, in Bangladesh situation some aspects of minority complex in a teacher may be mentioned as follows: "I have no time to talk with you; I have to remain busy." Such types of pretext are most of time used while any researcher meets him or discusses with him about the project. Thus to complete the whole project, a researcher of M. Phil and PhD program has to spend more than 8-9 years. He has nothing to do with the supervisor. Again, he mustn't disturb his supervisor if it goes beyond the supervisor's decision, his project may not be completed. This hanging situation is on the increase day by day in Bangladeshi universities. If this situation of minority complex always continues in between teachers and researchers, no country or no nation can develop scientific project in the field of research. To get rid of minority complex from the mind of teachers and researchers, practical measurements must be taken concertedly so that there is no barrier among them.

\section{IMPORTANT STEPS FOR RESEARCH WRITING}

In my opinion, to remove the major impediments of research writing in Bangladesh situation, pragmatic steps are very essential. If we fail to solve these barriers in a proper time, it will be very difficult for us to upgrade the strategies of scientific project; and we cannot keep abreast with the current Global Educational System. Steps should be taken right now so that new scholars and teachers can be able to enhance the potentiality of scholarly writing. Anywayresearch oriented teaching and learning ought to be implemented as earliest possible.

However, I have tried utmost to find out some practical aspects of research writing. They are as follows:

\section{Provide Funding Supports}

In Bangladesh, there are many poor and brilliant students, who have no ability to carry out a potential research project despite will and motivation. Most of the students come of very poor families, including- drivers, farmers, and day labours across the country. They are financially handicapped and poverty stricken. Due to familial crisis, they fail to conduct a scholarly writing. Another reason may be mentioned in this regard, most of them have no knowledge of research methodology, but they have bookish knowledge and their academic result is bright. But the major problem is that they are deprived of research methodology. They have no idea how to write a scholarly research project, how to cite, how to document sources, how to acknowledge, how to incite, how to organize, and how to comment. If they are able to come up with this basic knowledge, certainly they will deserve for any type of scientific research project.

To develop research writing situation in Bangladesh, we need urgently funding supports from the Government and the capitalist figure in society. It is the foremost duty of the Government to implement the hidden dreams of the poor research scholars, for this research budget should be increased in education sector.

If a country fails to provide funding supports for the poor and bright students, it is quite difficult for them to carry out a scientific research project. They need money, necessary materials, suitable environment, supervisors, proper guidance, research and teaching assistantships to carry out his scholarly project. But in a third world country, like Bangladesh, our students cannot afford to conduct his scientific project due to proper funding supports. If we look at the financially developed countries of the world, we can see that the Government provide abundant funding supports for researchers and teachers so that they don't have to face any sorts of troubles in carrying out a scientific research project.

\section{Establish Research Centre}

Research centre is such a place where teachers, research scholars, and students get themselves involved in conducting a potential research project all the time. In the research centre all sorts of branches of knowledge are explored and investigated to find out a new aspect of a potential research project. The contribution of research centre beggars description in words and language in the field of knowledge. 
Impediments for Research Writing in Bangladesh: Steps and Potentiality

If any research scholars cannot get facilities of research centre where they reside, it would be very difficult for them to carry out a project. Research centre should be established where needed or according to the demands of researchers. Generally research centre is established at the University area.

Through research centre, students can learn and gather knowledge of research project and research methodology. Sometimes the concerned authority of the research centre organise conference, seminar, workshop, symposium, and mini talks about research writing. From research centre, many novice researchers and young teachers take training of research methodology. In this way they gather practical experience regarding potential research project. The authority of the university should take initiatives to establish research centre so that students and teachers can investigate innovative research project. We should bear in mind that research centre can play an important role in conducting a scientific research project around the globe.

In Bangladesh situation, there are only few research centres at the University area or in another place of the country. Each university has a science laboratory, where students get entangled in practical class. There they can investigate and explore and they can be able to give us new information of a potential research project. It is clear that research centre is a must. So the Government as well as the conscious citizens should take necessary steps to found research centre so that the younger generation of any country can explore and investigate a potential research project.

\section{Increase the Use of Science and Technology}

We live in the age of science and technology. Everywhere we see the contribution of science and technology. We cannot think of our existence without science and technology. The developed countries of the world have reached the pinnacle of prosperity due to the use of science and technology. If a country wants to develop economically, it must increase the use of science and technology. But it is a matter of great regret that the third world countries of the world are lagging behind due to the underdevelopment of science and technology. If we think of a developing country, like Bangladesh, we will see that out country is not more developed in the field of science and technology. To develop the situation of science and technology, the conscious citizens of the country will have to come forward concertedly.

What I want to present here is that our potential research project should be science and technology oriented. Consequently, we can be able to reach the satisfactory level of the competitive age. In this regard, I can mention that there are some universities of Science and Technology in Bangladesh. The concerned authorities of these universities should take immediate steps to develop the use of science and technology. They should undertake initiatives to establish Science and Technology Research Centre so that teachers and researchers can carry out their research project freely and for this the concerned authority should allocate funding supports for the research oriented persons.

Now-a-days there are many students and teachers who are very much interested to conduct a potential research project under the Science and Technology Research Centre. If they are financially supported, they can do much better and not merely that they can be able to compete with the European scholars. So if we would like to practise epistemology, we must develop the use science and technology.

An important matter may be mentioned here is that we must ensure the use of plagiarism software checkers for any kind of research-work so that the supervisors can be able to check out the plagiarized writing of the potential research project. Plagiarism free research writing must be ensured for researchers and scholars. If we look at the researchers and supervisors of the developed countries of the globe, we see that they check out the research project through plagiarism software before review and evaluation process. It is very much common in the top ranking universities of the world. 
Impediments for Research Writing in Bangladesh: Steps and Potentiality

\section{Organize International Conference, Seminar, and Workshops}

International Conference, Seminar, and Workshop are the only way through which scholarly research writing might be feasible to develop. Different types of presenters and participants gather and share their person thoughts and ideas each other in the conference. Generally prominent scholars and researchers come from different parts of the world with a view to playing their roles as a paper presenter, keynote speaker, plenary speaker, and session chair in the program. Their main motto is to highlight the new aspects of potential research project in different ways. In this way the matter of research writing becomes apparent to young teachers and novice researchers; and they begin to realize the practical experiences of scholarly writing from the international scholars and researchers.

If we organise conference, seminar, workshop, symposium and round table talks in the Bangladesh Educational Institution frequently, we must be able to develop our thoughts and ideas of any research project very easily. The reason is that many international personnel will participate in the highly educative function from the world around. They will present different papers on many aspects of science and epistemology. Those who would participate there must gather new experiences and knowledge through different culture and community of the world. As a result the thoughts and concepts of young teachers and novice researchers must be broadened; and they would be able to contribute in the field of philology and other branches of knowledge. To enhance scholarly writing, conference, seminar, workshop, symposium and round table talks must play important functions for researchers and teachers.

If we look at the top ranking universities of the European World, we will observe that every month the teachers of different departments organize such international programs. That is why their potential research project is perfect and innovative in accordance with the demand of the postmodern age. On the contrary, if we look at the developing countries of the world, we will see that the scenario is totally opposite. Due to financial crisis, the poor countries cannot afford to organize such educative functions. As a result, the students, teachers, and researchers are fully deprived of a perfect research project. The case is same in Bangladesh.

Anyway, to remove impediments for scholarly writing in Bangladesh situation, we must concertedly organize conference, seminar, workshop, symposium and mini talks at each educational institution, and then it would be possible for us to develop the education system across the country. Since the prosperity of scholarly writing relies upon the international program, the Government and the conscious people of the country must take initiatives to fulfil the targets. There is no alternative way of International Conference if we want to cope with the competitive age.

\section{Come in Touch with Research Professors}

To develop and enhance the potentiality of scholarly writing, novice research scholars should come in touch with the renowned professors of the country. Generally, there is a popular notion that subject based professors are conversant with different subjects. They are regarded as very knowledgeable person on their expertise. They have research publications in the International Renowned Journals of the world around. They have vast experiences and knowledge on many issues. They are regarded as the asset of the University and the nations. If they utilize and apply their practical knowledge for the younger generation of the country, undoubtedly, it may be said that the young teachers and researchers can be properly benefitted from the sage professor in many respects.

It is the duty as well as responsibility of the subject wise experts and professors to motivate the young teachers and novice researchers so that they can be able to change a new framework of the whole potential research project. For this they should be given opportunity to take research training course from the research directors and professors of the University of the Globe around.

American Research Journal of English and Literature

Page 10 
If the interested researchers would like to develop and increase their research skill, they should not sit idly at home, rather they should come from their traditional concepts. They should keep abreast themselves in research writing and they should take preparation so that they can be able to cope with the outer world around them and they should investigate what is happening around the world.

We all know that the potential research writing is undergoing a significant change and its innovation is on the increase day by day. Therefore, I think that we should keep our eyes open out to see the unseen and to know the unknown from acquiring experiences from the great and the small.

There should be no difference between the high and low. In this regard, we should bear in mind that "to acquire knowledge and to serve for the greater humankind, but not keep it for your own sake."

From the above discussion, we can come to concluding remark that our current Government should take immediate steps so that young teachers and novice researchers can be able to enjoy and ensure funding supports, research centre, conference, symposium, workshop, and mini-talks at very educational institutions of Bangladesh. I am confident that the above mentioned steps are taken very carefully, research writing can be developed and may scholarly wring be our only motto as a constant company of life.

\section{POTENTIALITY OF THE RESEARCH WRITING}

The prosperity and failure of Educational System of a country largely relies upon the practice of research writing. If there is no any practice of research writing at University level of Bangladesh, no student can expect to get scholarship or funding support while he plans to study in any parts of the world. To get financial support in abroad, the main weapon is the research writing; for this younger generation must try to write articles, short commentary, and review creatively and try to publish them in the renowned journals of the world. Research writing obviously helps a student sharpen and broaden his thoughts and ideas clearly and minutely. It makes him fit in such a way that he can be able to coin new diction, word, phrase, and sentence like a pure scientist. He tries to invent own theory and then he would apply his own formulae in research writing. In this way, he would be able to become a votary of research writing automatically.

If we look at a scientist, like Thomas Alva Edison, we will behold that Edison came of a very family; he had no formal education in his life. He restlessly worked harder and harder to invent scientific equipment, like a bulb, day and night like an ant. But even today, we cannot deny his scientific contribution. He was a poor pure scientist unlike Einstein or Stephen Hawking. He knew nothing of scientific theory, but he had achieved practical experiences while he had kept himself busy to invent something new. He didn't know himself what he was seeking and what he was inventing. Another example may be drawn is that Shakespeare had composed tragedy and comedy just for the entertainment of the age, his aim was to teach the people through his dramatic writing; he did not know dramaturgy or literary theory like a University professor. He had god gifted knowledge like Edison. He wrote plays cats and dogs throughout his life times. His plays have been translated and retranslated in many languages throughout the world. He is like a literary scientist. The case is the same a poor research scholar would always be devoted to research writing; he would continuously write and innovate something pure and perfect for all. He is a seeker like Marco Polo.

What I mean to present here is that the potentiality and depth of research writing beggar descriptions in words and language. I think that the duty and responsibility of a practical research scholar is to practise and conduct his scientific research project throughout the span of life.

\section{CONCLUSION}

Finally, we can say that research writing is the part and parcel of Bangladesh Education System. If there is no practice of research writing in education, that education cannot be a real learning. The main purpose of education is to make novice researchers and young teachers conscious of scholarly writing. It can broaden 
his outer attitudes and thoughts regarding creative writing, through this practice he can face himself with the global education. He can be able to seek a lucrative job through scholarly writing, he can be able to promote himself in his professional career and at the same time he would get scholarship and funding support at home and abroad. His reputation and popularity will be on the increase through the regular practice of research writing. If he wants to satisfy this research work perfectly and properly, he must be a devotional figure and perfect scholar.

In this competitive age, research writing in all branches of epistemology, like science, arts, commerce is on the increase randomly around the world. Research oriented teaching and learning should be implemented at every stage of Bangladesh Educational Institutions. If is the duty and responsibility of all sorts of intellectuals and educative persons of the country should take pragmatic measurements and decision to spread the practice of research writing across the country.

In Bangladesh research writing is less valued and evaluated, because we have a wrong notion that there is no profit or benefit of research writing, it won't help us financially. We should come out from this traditional idea; rather we should go ahead to cope with the experts of European countries.

What the current research scholar would like to present through this study is to motivate and inspire the novice researchers and young teachers. We know that we have to face a lot of impediments for research writing. We have no ample opportunity of funding or scholarship at our education institutions. Yet we shouldn't lag behind from out real motif. This study would like to make researchers conscious of unknown and unseen research project. To see the unseen and to know the unknown is the real aim of scholarly research project. Everybody knows but he never thinks out carefully in the form of research writing.

Anyway, the present government as well as the apprentice should take a wise decision so that the barriers of research writing can be solved with concerted efforts.

\section{REFERENCES}

Murray, A. Montessori elementary philosophy reflects current motivation theories. Montessori Life.23(1), 2011, pp. 22-33.

Pintrich, P. R. A motivational science perspective on the role of student motivation in learning and teaching contexts.Journal of Educational Psychology.95(4), 2003, pp.667-686.

Rigby, C. S. Deci, E. L., Patrick, B. C., \& Ryan, R. M. Beyond the intrinsic-extrinsic dichotomy: Self-determination in motivation and learning. Motivation and Emotion.16 (3), 1992, pp165-185.

Steneck, N. H. ORI-Introduction to the Responsible Conduct of Research, Washington D.C. , U.S. Government Printing Office, 2007,p.3.

Citation: Md. Amir Hossain, "Impediments for Research Writing in Bangladesh: Steps and Potentiality" American Research Journal of English and Literature, vol 4, no. 1, 2018, pp. 1-12.

Copyright (C) 2018 Md. Amir Hossain, This is an open access article distributed under the Creative Commons Attribution License, which permits unrestricted use, distribution, and reproduction in any medium, provided the original work is properly cited. 